\title{
Identification of superior progenies between common bean gene groups for root system obtained by recurrent selection
}

\author{
Paulo Henrique Cerutti1 ${ }^{1, \star}$ (D), Rita Carolina de Melo ${ }^{1}$ D , Jucimara Alves Silva ${ }^{1}$ D, Ana Carolina da Costa \\ Lara Fioreze $^{2}$ (D), Silmar Primieri ${ }^{3}$ (D), Altamir Frederico Guidolin ${ }^{1}$ (D), Jefferson Luís Meirelles Coimbra ${ }^{1}$ (D) \\ 1. Universidade do Estado de Santa Catarina - Instituto de Melhoramento e Genética Molecular - Centro de Ciências Agroveterinárias - Lages \\ (SC), Brazil. \\ 2. Universidade Federal de Santa Catarina - Instituto de Genética e Melhoramento Vegetal - Centro de Ciências Rurais - Curitibanos (SC), Brazil. \\ 3. Instituto Federal de Educação, Ciência e Tecnologia de Santa Catarina - Departamento de Ciência do Solo - Laboratório de Microbiologia do \\ Solo-Lages (SC), Brazil.
}

Received: Nov. 28, 2020 | Accepted: Jan. 18, 2021

Section Editor: Freddy Mora

*Corresponding author: paulohcerutti@gmail.com

How to cite: Cerutti, P. H., Melo, R. C., Silva, J. A., Fioreze, A. C. C. L., Primieri, S., Guidolin, A. F. and Coimbra, J. L. M. (2021). Identification of superior progenies between common bean gene groups for root system obtained by recurrent selection. Bragantia, 80, e1521. https://doi. org/10.1590/1678-4499.20200487

\begin{abstract}
Genetic variability is essential for gains in breeding programs. The cyclic process of progeny recombination is a strategy to raise the chances of selecting better genotype combinations. The objective of this study was to identify superior progenies between common bean genes groups in first recurrent selection cycle for root system traits. Parents of the Andean and Middle American gene groups were hybridized in a complete diallel scheme. Thereafter, the parents and $F_{1}$ and $F_{2}$ populations were planted in the field. To establish the base population of recurrent selection $\left(C_{0}\right)$, seven segregating populations $\left(F_{2}\right)$ with superior performance for root system were selected and intercrossed, resulting in recombinant progenies $\left(C_{1}\right)$. To estimate the selection gain, the parents and $C_{0}$ and $C_{1}$ genotypes were compared with regard to the following variables: total root length (TRL, $\mathrm{cm}$ ), projected root area (PRA, $\mathrm{cm}^{2}$ ), root volume $\left(\mathrm{VOL}, \mathrm{cm}^{3}\right)$ and number of root tips (RT). The difference between genotype combinations indicates the presence of genetic variability and effectiveness of recurrent selection. The mean genetic progress for root system-related traits was $12.9 \%$ (TRL), $12.6 \%$ (PRA), $12 \%$ (VOL) and $11.5 \%$ (RT) in the first recombination cycle. The mean phenotypic performance of seven of the $C_{1}$ progenies exceeded that of their parents for all root system traits. These progenies are promising as base populations of the next selection cycle.
\end{abstract}

Key words: Phaseolus vulgaris L., Genetic variability, Genetic progress.

\section{INTRODUCTION}

Over the course of time, breeding programs have been successful in the development of agronomically superior genotypes. For common bean (Phaseolus vulgaris L.), as well as other crops, breeding efforts have mainly addressed higher grain yields (Silva et al. 2013; Pereira et al. 2016). However, due to the yield instability of common bean cultivars under adverse cultivation conditions, the root system has come to be considered a key aspect to be evaluated in breeding programs (Amongi et al. 2015; Silva et al. 2016).

The presence of genetic variability and the low targeting of breeding programs for root system trait makes genetic gain possible. In addition to the source of alleles, this is possible because the direct selection for this trait has not been performed by beans breeders in Brazil. In the case of common bean, a major part of the diversity of the species is represented in two gene groups. The Andean gene group comprises genotypes with large seeds (35-50 g/100 seeds), 'T' phaseolin type and 
growth habits I and IV. The Middle American group, on the other hand, includes genotypes with small seeds (20 g/100 seeds), 'S' phaseolin type and growth habits II and III. The root systems of the groups are also contrasting. A predominantly superficial root system $(0-10 \mathrm{~cm})$ was reported for the Andean group, while root development into deeper soil layers was observed in the Middle American group (Nienhuis and Singh 1988; Beebe et al. 2013; Polania et al. 2016).

Despite the knowledge about the genetic divergence between Andean and Middle American populations, the study of recombinant populations between these groups for root traits is still rather rare. Therefore, plant breeders have to seek allele sources in germplasm banks to develop a desired ideotype (Beebe et al. 2008). In autogamous plant breeding programs, after the identification of genes of interest, gene recombination is a routine process, followed by cultivation and selection of segregating populations by successive selfing. However, the efficiency of this procedure may be suboptimal, in particular for traits controlled by many genes (Ramalli 1996).

In this sense, aside from the combination of distinct gene groups, the use of recurrent selection in autogamous plants can increase the effectiveness of development of improved genotype combinations. Thus, intercrosses of superior plants may result in: i) greater genetic variability, ii) greater opportunity for allelic recombination (by successive hybridizations), iii) better breakup of gene blocks and thus, iv) higher frequency of favorable genes for root system expression (Hallauer and Darrah 1985; Guimarães 1997; Ramalho et al. 2005; Silva et al. 2010; Alves et al. 2015).

For the above-ground plant parts of common bean, numerous recurrent selection studies have already addressed variables such as crop cycle, growth habit, grain yield, grain appearance, disease resistance and others (Ramalho et al. 2005; Silva et al. 2010; Silva et al. 2013; Souza et al. 2014; Alves et al. 2015; Leite et al. 2016; Pereira et al. 2016; Anjos et al. 2018). The scarcity of studies focused on the root system might be related to the difficulty of phenotyping this trait in a large number of progenies. However, the study and identification of progenies with a better root system has become primordial in recent years. The consideration and evaluation of this trait in breeding programs allows the formation of genotypes with adaptive characteristics (greater water absorption and mineral resources), which enhances their cultivation in non-ideal environmental conditions. Thus, the purpose of this study was to identify superior progenies for root system traits in the first recurrent selection cycle between Andean and Middle American common bean gene groups.

\section{MATERIAL AND METHODS}

Annual experiments were carried out from 2016 to 2019 in Lages (SC). Initially, in 2016, six common bean parents of the Andean and Middle American groups were hybridized in a complete diallel scheme, resulting in 30 hybrid populations. Parents with contrasting traits (root system, gene group, market group and growth habit) were chosen based in previous experiments. The 36 genotypes (six parents and 30 hybrids), were then cultivated in the field in the 2016/17 growing season and evaluated in a completely randomized design with two replications.

In the 2017/18 growing season, the six initial diallel parents, along with 30 hybrids and $28 \mathrm{~F}_{2}$ populations, were planted again in the field in a single lattice $(8 \times 8)$ design with two replications. The root system was evaluated in both experiments (2016/17 and 2017/18 growing seasons). The particular focus was the variable root distribution (RD), which was phenotyped according to Böhm's (1979) methodology, with adaptations. This methodology was chosen because it is one of those used to evaluate the non-destructive root system of plants in the field. The evaluation consisted of opening a trench perpendicular to the plant row to expose the plant root system. According to the methodology, a $0.50 \times 0.30 \mathrm{~m}$ frame, subdivided in $0.05 \times 0.05 \mathrm{~m}$ squares, was placed within the profile.

Thus, the root distribution was determined based on binary data, corresponding to the presence (1) and absence (0) of roots in each of the 60 grid squares. Field evaluations of the variable root distribution are important in the discrimination of genotypes for commercial cultivation. The data of this variable provided information about the genotypes with regard to the horizontal and vertical exploitation of roots in the soil.

After the evaluation of genotype combinations in the 2017/18 growing season, seven progenies of the segregating generation $\mathrm{F}_{2}$ were selected (based on the better performance for $\mathrm{RD}$ compared to their parents) to constitute the base population $\mathrm{C}_{0}$ of the recurrent selection. Recurrent selection cycles recommend the selection of superior individuals to compose the initial 
recombination population. To initiate the recurrent selection cycle, the seven selected populations were intercrossed in a greenhouse, resulting in 28 new populations, named $\mathrm{C}_{1}$ populations (progenies of recurrent selection cycle one).

Finally, to estimate the genetic gain in cycle one $\left(\mathrm{C}_{1}\right)$ and identify superior progenies of recurrent selection for root system traits in the 2018/19 growing season, an experiment was performed in a greenhouse with five lines of the initial diallel, along with seven $\mathrm{C}_{0}$ populations and $23 \mathrm{C}_{1}$ progenies (35 genotypes) (Table 1). To this end, a randomized complete block design with three replications was used.

Table 1. Genotype combinations used to estimate selection gain for root system variables (last experimental phase from January - February 2019). Description of parents, original $\left(C_{0}\right)$ and selected $\left(C_{1}\right)$ progenies for the first recurrent selection cycle of common bean.

\begin{tabular}{|c|c|c|}
\hline & Genotypes & Gene group \\
\hline & 1 & Middle American \\
\hline & 2 & Middle American \\
\hline \multirow[t]{14}{*}{ Parents } & 3 & Andean \\
\hline & 4 & Middle American \\
\hline & 5 & BRS Embaixador \\
\hline & 6 & BAF07 $\times$ BAF53/BAF07 $\times$ CBS14 \\
\hline & 7 & BAF07 × BAF53/IPR Uirapuru × BRS Embaixador \\
\hline & 8 & BAF07 $\times$ BAF53/BAF53 $\times$ IPR Uirapuru \\
\hline & 9 & BAF07 $\times$ BAF53/BRS Embaixador $\times$ BAF07 \\
\hline & 10 & BAF07 × BAF53/BRS Embaixador $\times$ IPR Uirapuru \\
\hline & 11 & BAF07 $\times$ CBS14/BAF35 $\times$ BRS Embaixador \\
\hline & 12 & BAF07 $\times$ CBS14/IPR Uirapuru $\times$ Embaixador \\
\hline & 13 & BAF07 $\times$ CBS14/BAF53 $\times$ IPR Uirapuru \\
\hline & 14 & BAF07 × CBS14/BRS Embaixador $\times$ IPR Uirapuru \\
\hline & 15 & BAF35 $\times$ BRS Embaixador/IPR Uirapuru $\times$ BRS Embaixador \\
\hline & 16 & BAF35 × BRS Embaixador/BAF53 × IPR Uirapuru \\
\hline \multirow[t]{15}{*}{$\mathrm{C}_{1}$ progenies } & 17 & BAF35 × BRS Embaixador/BRS Embaixador $\times$ BAF07 \\
\hline & 18 & BAF35 × BRS Embaixador/BRS Embaixador $\times$ IPR Uirapuru \\
\hline & 19 & BAF35 × BRS Embaixador/BRS Embaixador $\times$ BAF53 \\
\hline & 20 & IPR Uirapuru × BRS Embaixador/BAF53 × IPR Uirapuru \\
\hline & 21 & IPR Uirapuru × BRS Embaixador/BRS Embaixador × BAF07 \\
\hline & 22 & IPR Uirapuru $\times$ BRS Embaixador/BRS Embaixador $\times$ IPR Uirapuru \\
\hline & 23 & IPR Uirapuru × BRS Embaixador/BRS Embaixador × BAF53 \\
\hline & 24 & BAF53 × IPR Uirapuru/BRS Embaixador × BAF07 \\
\hline & 25 & BAF53 $\times$ IPR Uirapuru/BRS Embaixador $\times$ IPR Uirapuru \\
\hline & 26 & BAF53 $\times$ IPR Uirapuru/BRS Embaixador × BAF53 \\
\hline & 27 & BRS Embaixador $\times$ BAF07/BRS Embaixador $\times$ IPR Uirapuru \\
\hline & 28 & BRS Embaixador $\times$ IPR Uirapuru/BRS Embaixador $\times$ BAF53 \\
\hline & 29 & BAF07 × BAF53 \\
\hline & 30 & BAF35 $\times$ BRS Embaixador \\
\hline & 31 & IPR Uirapuru $\times$ BRS Embaixador \\
\hline \multirow[t]{4}{*}{$\mathrm{C}_{0}$ populations } & 32 & BAF53 × IPR Uirapuru \\
\hline & 33 & BRS Embaixador $\times$ BAF07 \\
\hline & 34 & BRS Embaixador $\times$ IPR Uirapuru \\
\hline & 35 & BRS Embaixador $\times$ BAF53 \\
\hline
\end{tabular}


The experiment to identify superior progenies $\left(\mathrm{C}_{1}\right)$ of the first selection cycle in relation to the base populations $\left(\mathrm{C}_{0}\right)$ and parents, comparatively, was carried out in a greenhouse, because some progenies had a low number of available seeds. This was observed mainly in progenies of different gene groups, possibly due to the genetic distance of the groups, already reported in the literature. Furthermore, a new methodology (digital analysis software WinRHIZO), widely used in the literature for root phenotyping, has been adopted. However, it is still in the adaptation phase for the root system evaluation in field, being more used in controlled conditions. The mathematical model representing the experimental conditions can be expressed as in Eq. 1:

$$
\mathrm{Y}_{\mathrm{ij}}=\mu+\text { block }_{\mathrm{i}}+\text { genotype }_{\mathrm{j}}+\varepsilon_{\mathrm{ij}}
$$

where $\mathrm{Y}_{\mathrm{ij}}$ represents the phenotypic value of a given characteristic, $\mu$ the overall mean, block the effect of the $\mathrm{i}^{\text {th }}$ level of the block factor, genotype $e_{j}$ the effect of the $j^{\text {th }}$ level of the genotype factor and $\varepsilon_{i j}$ the effect of uncontrolled sources on phenotypic observations. The 35 genotypes were sown in $4 \mathrm{~L}$ pots filled with commercial substrate. Irrigation inside the greenhouse was applied manually, distributed equally in each pot, around the stem of the plants. A volume of $6 \mathrm{~mm}$ of water was made available, according to the crop climatic requirements. Temperature and air humidity were measured and recorded by a data logger in $2 \mathrm{~h}$ intervals. Fertilization was applied according to technical recommendations for common bean (Fancelli and Dourado Neto 2007).

The plants were carefully removed from the pots trying to preserve the root system structure. Thereafter, the roots were rinsed in tap water and then stored in $70 \% \mathrm{alcohol} /$ water solution in order to preserve the structure of the root system. When all plants of all genotypes were collected, the root system was analyzed. The following variables were evaluated in the laboratory: i) total root length (TRL, in $\mathrm{cm}$ ); ii) projected root area (PRA, in $\mathrm{cm}^{2}$ ); iii) root volume (VOL, in $\mathrm{cm}^{3}$ ); iv) number of root tips (RT). Variables ii) and iii) were estimated based on the substrate volume of each pot. All information was processed by the digital analysis software WinRHIZO (v 5.0, Regent Instruments, Quebec, Canada). In this evaluation step, the root system of each plant, of each repetition was evaluated. The analysis consists of a digital reading of the root system. From this, images of the roots and the numerical quantification of each variable mentioned were obtained. The parameters were estimated by the expressions: v) heritability in the broad sense, $h^{2}=\sigma^{2} \mathrm{~g} / \sigma^{2} \mathrm{ph}$; vi) Intraclass correlation, $\mathrm{t}=\sigma^{2}$ among $/ \sigma^{2}$ among $+\sigma^{2}$ within; vii) selection gain, $\mathrm{SG}=\mathrm{h}^{2} \times \mathrm{sd}$; viii) Genetic progress, $\mathrm{GP}(\%)=\left(\mathrm{SG} / \overline{\mathrm{X}}_{0}\right) \times 100$, where $\sigma^{2} \mathrm{~g}=$ genetic variance, $\sigma^{2} \mathrm{ph}=$ phenotypic variance, $\sigma^{2}$ among $=$ variance among plants, $\sigma^{2}$ within = variance within plants, $s d=$ selection differential and $\overline{\mathrm{X}}_{0}=$ original population mean. The resulting information was tested for normality of residuals and homogeneity of variances. All estimates and mean comparisons were established using SAS software (University Edition), using the general linear model (glm) procedure, using probability of $\mathrm{p}<0.05$.

\section{RESULTS AND DISCUSSION}

The mean square value of genotypes was significant by the F statistic $(\mathrm{p}<0.05)$ for all response variables (Table 2$)$. This fact reveals the existence of genetic variability among the 35 genotypes. Monitoring and use of genetic variability are fundamental at the beginning of any breeding program. If available, traits of agronomic interest can be combined in the target population (Allard 1971).

Moreover, one of the assumptions underlying recurrent selection is the preservation of genetic variability throughout the cycles (Hallauer and Darrah 1985). In other words, the population will be improved by the recurrent selection process without losing genetic variability. The significance of the treatment effect was also mentioned for characteristics related to grain yield and common bean plant architecture in two selection cycles (Alves et al. 2015).

To analyze the contribution of each genotypic class to the total variation, the treatment mean square was initially partitioned into effects corresponding to parents, $\mathrm{C}_{0}$ populations, $\mathrm{C}_{1}$ progenies and contrasts between genotypic classes (Table 2). The partitioning indicated a significant effect of all sources of variation by the $\mathrm{F}$ test $(\mathrm{p}<0.05)$ for all variables except the $\mathrm{C}_{0}$ populations, which did not differ significantly for any trait. The lack of variation in the $\mathrm{C}_{0}$ population indicated that the phenotypic values for root system variables of the genotypes were similar. The highest mean square 
effect was observed for the contrast $\left(\mathrm{Gen} \times \mathrm{C}_{0} \times \mathrm{C}_{1}\right)$, emphasizing a possible divergence between populations throughout the selection cycles. This divergence indicates how good the chances are for genetic gains in a selection cycle. The reason is that the effectiveness of recurrent selection cycles is related to the level of genetic variability in the population for the target variables (Fehr 1987). Thus, this breeding scheme based on the recombination of superior plants can maintain the genetic variability of a population and simultaneously increase the frequency of desirable genes due to the resulting gene combinations (Allard 1971). In other studies, significant differences were also reported between populations improved in selection cycles, compared to the parents and progenies for the traits: hypocotyl diameter, plant architecture, grain yield and white mold susceptibility in common bean. (Souza et al. 2014; Anjos et al. 2018).

Table 2. Analysis of variance (values of degrees of freedom and mean squares) for the variables TRL, PRA, VOL and RT in common bean.

\begin{tabular}{|c|c|c|c|c|c|}
\hline \multirow{2}{*}{ Source of variation } & \multirow{2}{*}{$\mathrm{DF}^{1}$} & \multicolumn{4}{|c|}{ Mean squares } \\
\hline & & TRL (cm) & PRA $\left(\mathrm{cm}^{2}\right)$ & $\operatorname{Vol}\left(\mathrm{cm}^{3}\right)$ & RT \\
\hline Block & 2 & $1034182^{\text {ns }}$ & $95005^{\text {ns }}$ & $559479^{\text {ns }}$ & 10412099 \\
\hline Genotypes & (34) & $3648564^{\star}$ & $457649^{*}$ & $3711193^{\star}$ & $3273073^{*}$ \\
\hline Parents & 4 & $2400483^{\star}$ & $265456^{\star}$ & $1830895^{\star}$ & $1006804^{*}$ \\
\hline $\mathrm{C}_{0}^{2}$ & 6 & $2954819^{\text {ns }}$ & $267084^{\text {ns }}$ & $1708995^{\text {ns }}$ & $2795135^{\text {ns }}$ \\
\hline $\mathrm{C}_{1}^{3}$ & 22 & $2049353^{*}$ & $304305^{*}$ & $2843096^{*}$ & $1875946^{*}$ \\
\hline Parents $\times \mathrm{C}_{1} \times \mathrm{C}_{0}$ & 1 & $33693671^{*}$ & $4232427^{\star}$ & $33265484^{*}$ & $1023007^{*}$ \\
\hline $\mathrm{C}_{1} \times \mathrm{C}_{0}$ & 1 & $18409506^{*}$ & $2006745^{\star}$ & $12920000^{*}$ & $9995484^{*}$ \\
\hline Error & 64 & 1357940 & 162984 & 1274869 & 1023007 \\
\hline Total & 100 & & & & \\
\hline$\sigma_{g}^{2(4)}$ & & 794693 & 102229 & 845241 & 788623 \\
\hline $\mathrm{hb}^{2}(5)$ & & 0.37 & 0.39 & 0.40 & 0.44 \\
\hline$\hat{\mathrm{t}}^{(6)}$ & & 0.28 & 0.51 & 0.32 & 0.50 \\
\hline $\operatorname{SD}(\hat{\mathrm{t}})^{(7)}$ & & \pm 0.11 & \pm 0.09 & \pm 0.11 & \pm 0.12 \\
\hline
\end{tabular}

'Significant at $5 \%$ probability by the $\mathrm{F}$ test. ${ }^{1}$ degrees of freedom; ${ }^{2}$ base populations; ${ }^{3}$ progenies of recurrent selection; ${ }^{4}$ genetic variance; ${ }^{5}$ heritability in the broad sense; ${ }^{6}$ intraclass correlation and ${ }^{7}$ standard deviation associated with the intraclass correlation estimate.

Once the genetic divergence between treatments is known, genetic components can be estimated. The magnitude of genetic variance $\left(\sigma^{2} \mathrm{~g}\right)$ was between 788623 and 102229 (Table 2). The $\sigma^{2} \mathrm{~g}$ was calculated by estimating the covariance between phenotypic and genotypic values $(\mathrm{COV} \mathrm{Ph} / \mathrm{G})$. The $\sigma^{2}$ g values indicate exclusively the genetic fraction related to the phenotypic expression. Summing up, the $\sigma^{2}$ g indicates how much of the total variance is likely to be transmitted from parents to the respective progenies. Thus, the values obtained for the root system characteristics of the parents will probably be expressed in the segregating populations. Since the $\sigma^{2} \mathrm{~g}$ values are transmitted to the progenies, the chances of an effective selection progress during the population advancement in the breeding program is increased. Thus, the existence of covariance between selected populations and their descendants allows the prediction of gains and the possibility of success in selecting plants (Vencovsky and Barriga 1992). In general, the recurrent selection process will only be effective if genetic variance is available and detectable in the breeding population (Ramalho et al. 2005; Silva et al. 2007).

The fraction of phenotypic variation due to the genetic component (heritability) is also related to the estimated COV $(\mathrm{Ph} / \mathrm{G})$. In this study, the broad-sense heritability was analyzed, since, aside from the additive, non-additive genetic variance may also be found among progenies derived from the recurrent selection process. The estimated heritability coefficient values for root system variables ranged from 0.37 to 0.44 (Table 2$)$. Heritability estimates have a medium magnitude $(<0.50)$. Medium to low values for root system variables have already been reported in the literature, as this characteristic is clearly affected by environmental influences (Melo et al. 2016). For flowering duration (in days) of common bean, the heritability was approximately 0.87 after five recurrent selection cycles. For growth habit, a mean heritability of 0.55 was reported for common bean after four recurrent selection cycles (Silva et al. 2007; Leite et al. 2016). 
The effectiveness of genotype selection for variables of interest is closely related to the magnitude of the genetic and nongenetic factors involved in the phenotypic expression (Allard 1971). Heritability thus indicates the chances for a successful selection. For example, in phenotypic recurrent selection stages for root system, higher heritability values increase the security in choosing genetically superior plants. It is also worth noting that the $\sigma^{2} \mathrm{~g}$ and heritability estimates analyzed in the populations of selection cycle one compared with the other populations indicate the possibility of gains with the next recurrent selection cycles.

As pointed out, the expression of any trait of interest is the result of genetic, environmental and interaction effects. Thus, it is convenient to estimate the correlation between the data of plants in a population. Aside from the estimates of $\sigma^{2} \mathrm{~g}$ and heritability, the ratio of variances among plants by total variation is worth mentioning in breeding programs. The intraclass correlation estimates $(\mathrm{t})$ varied from 0.28 to 0.51 (Table 2). The estimate of the variable projected root area $\left(\mathrm{cm}^{2}\right)$ was the highest. The values of standard deviation associated with intraclass correlation were low, indicating the accuracy of estimation (Table 2). The intraclass correlation component is closely associated with a probable prediction of the future performance of a plant, based on the population mean. Even though few plants are evaluated (due to the low number of seeds of some combinations), the intraclass correlation coefficient indicates the relevance of this study, being considered medium to high for quantitative characteristics. In general, higher values of intraclass correlation (or repeatability) indicate that, e.g., fewer plants have to be evaluated to represent phenotypic values in the segregating population stages. For grain yield-related characteristics of cowpea, repeatability coefficients from 0.40 to 0.57 were reported (Torres et al. 2015). In this study, medium to low intraclass correlations were found. The genetic variability was maintained during the selection cycle and recombination of segregating generations. Due to this maintenance of variability, a higher number of plants should be evaluated in future stages of the breeding program.

Once the recurrent selection cycle one was completed, significant increases were observed by the t-test $(\mathrm{p}<0.05)$ in the mean of the $C_{1}$ progenies in relation to the parents $\left(C_{1} \times\right.$ parents $)$ and base population $C_{0}\left(C_{1} \times C_{0}\right)$ for all variables (Table 3). This fact highlights the presence of gains by recurrent selection. The effect of selection sought by the breeder is the improvement in the population mean of the target variable of selection. This change is called genetic progress or response to selection. The estimated genetic progress of progenies from $\mathrm{C}_{1}$ to $\mathrm{C}_{0}$ for the four variables covered an estimated range of 11.5 to $12.9 \%$. These percentage values indicate the mean increase per trait and selection cycle. Furthermore, they highlight the possible effectiveness of the phenotypic recurrent selection process. Gains by initial recombination cycles, for example from 3.3 to $9 \%$ for common bean grain yield, have already been reported (Silva et al. 2010; Alves et al. 2015).

Table 3. Means and selection gains for each genotypic class (parents, $C_{0}$ and $C_{1}$ ) for the variables TRL, PRA, VOL and RT in common bean.

\begin{tabular}{|c|c|c|c|c|}
\hline Classes & TRL (cm) & PRA $\left(\mathrm{cm}^{2}\right)$ & $\operatorname{VOL}\left(\mathrm{cm}^{3}\right)$ & RT \\
\hline Parents & 2280 & 782 & 2110 & 1804 \\
\hline $\mathrm{C}_{0}$ & 3078 & 1085 & 3033 & 2955 \\
\hline $\mathrm{C}_{1}$ & 4151 & 1442 & 3942 & 3746 \\
\hline $\mathrm{C}_{1} \times$ Parents & $1871^{*}$ & $660^{*}$ & $1832^{*}$ & 1942 \\
\hline $\mathrm{C}_{1} \times \mathrm{C}_{0}$ & $1073^{\star}$ & $357^{*}$ & $909^{*}$ & $791^{*}$ \\
\hline Overall mean & 3650 & 1268 & 3478 & 3287 \\
\hline Selection gain & 396 & 137 & 361 & 341 \\
\hline Genetic progress (\%) & 12.9 & 12.6 & 12.0 & 11.5 \\
\hline
\end{tabular}

Significant at $5 \%$ probability by the t-test.

Genetic progress was also mentioned for this crop, e.g., $7 \%$ for grain type, $33.4 \%$ for rust resistance, $13.2 \%$ for angular spot resistance, $4.95 \%$ for hypocotyl diameter and $4.93 \%$ for plant architecture (Anjos et al. 2018). The recurrent selection gains reported in this study were higher than gains in shoot traits, discussed in the literature. For example, grain yield and growth habit, among others, are characteristics with lowest gains in the initial recurrent selection cycles (Silva et al. 2010; Alves et al. 2015; Pereira et al. 2016). This fact is closely related to the direction of common bean and other crop 
improvement programs. In other words, the main objective of breeders throughout the breeding processes was mostly the search for superior genotype combinations for grain yield (Abenavoli et al. 2015). All traits closely related to grain yield have already been greatly improved by breeding programs, in contrast to the root-related characters. Thus, when selection cycles for yield and root are applied, the gains tend to be greater for the root system, even in initial recurrent selection stages.

In this study, increments in phenotypic means $\left(C_{1}\right.$ compared to $\left.C_{0}\right)$ were recorded for: TRL $(396 \mathrm{~cm}), \operatorname{VOL}\left(361 \mathrm{~cm}^{3}\right)$, RT (341) and PRA $\left(137 \mathrm{~cm}^{2}\right.$ ) (Table 3). Based on the increases in the variables above, the development of agronomically superior genotype combinations seems to be possible. These traits related to the root system morphology of common bean are directly responsible for the ability of a crop to exploit resources under heterogeneous soil and water regime conditions (Miguel et al. 2013). A better root development is correlated with a higher uptake of some poorly available nutrients (e.g., phosphorus) in the soil solution. Apart from the nutritional aspect, drought-stressed common bean genotypes with a more developed root system and greater root length and volume are advantageously able to take up water from deeper soil layers (Ho et al. 2005; Henry et al. 2010). Thus, it is essential to consider the genetic variability promoted for root system by recurrent selection cycles in common bean plants to mitigate the negative effects caused by stress conditions (Abenavoli et al. 2015).

As genetic progress has been achieved with the recurrent selection cycle, the superiority of segregating over fixed populations should be noted. All $\mathrm{C}_{0}$ progenies performed similarly to the parents, except for genotype 30 , which differed significantly for all variables (Table 4). It is worth emphasizing that this progeny was derived from the combination of the genotypes BAF35 $\times$ BRS Embaixador (Middle American $\times$ Andean). Aside from the gene group, the genotypes are contrasting for seed coat color and growth habit. Thus, the combination of the characteristics of both parents favored the expression of the root system. For the traits TRL and VOL, significant differences between Andean and Middle American parents were observed (Román-Avilés et al. 2003).

Table 4. Mean contrasts between seven base populations $\left(C_{0}\right)$ compared to the parents for TRL, PRA, VOL and RT in common bean.

\begin{tabular}{|c|c|c|c|c|}
\hline Genotype & TRL (cm) & PRA $\left(\mathrm{cm}^{2}\right)$ & $\operatorname{VOL}\left(\mathrm{cm}^{3}\right)$ & RT \\
\hline 29 & 1.96 & 1.50 & 0.98 & 0.34 \\
\hline 30 & $4.76^{*}$ & $4.53^{*}$ & $4.08^{*}$ & $5.68^{*}$ \\
\hline 31 & 1.48 & 0.83 & 0.39 & $4.37^{\star}$ \\
\hline 32 & 2.48 & 3.56 & $4.63^{*}$ & $7.65^{\star}$ \\
\hline 33 & 0.33 & 1.00 & 0.63 & 0.11 \\
\hline 34 & 1.87 & 1.66 & 1.40 & $4.32^{*}$ \\
\hline 35 & 0.96 & 1.36 & 1.72 & 2.71 \\
\hline
\end{tabular}

'Significant at $5 \%$ probability by the t-test. $\mathrm{H}_{0}: \mathrm{C}_{0}=$ Parents.

Similar results to those described for $\mathrm{C}_{0}$ populations, which indicate insignificant contributions of beneficial heterotic effects, were also found for grain yield (Moura et al. 2018). This situation is consistent with that of most agronomically important traits of autogamous plants (particularly of common bean). Most traits of this crop are controlled by genes with a strong additive nature. In the $\mathrm{C}_{0}$ populations, an irrelevant number of plants with deviations exceeding the parental mean was observed. In the $\mathrm{C}_{0}$ population, this could be explained by the insufficiently low number of favorable genes to constitute plants that outperform their parents. Moreover, even when favorable gene combinations occur, the establishment of promising plants is conditioned to the effectiveness of selection during selfing. If selection in the cultivation stages of segregating populations is not effectively practiced, the gene fixation of the traits occurs mainly randomly (Allard 1971).

Opposite to the progenies of $\mathrm{C}_{0}$, those of $\mathrm{C}_{1}$ were promising for root system characteristics. The performance of seven $\mathrm{C}_{1}$ progenies exceeded the mean of their parents for all root system variables (Table 5). This is consistent with the assumption that, in recurrent selection stages (even of autogamous plants), genetic variation of non-additive nature is also present in the phenotypic composition (Hallauer and Darrah 1985). 
Table 5. Mean contrasts between common bean populations of selection cycle one $\left(C_{1}\right)$ compared to the parents, for the variables TRL, PRA, Vol and RT.

\begin{tabular}{|c|c|c|c|c|}
\hline Genotype & TRL (cm) & $\operatorname{PRA}\left(\mathrm{cm}^{2}\right)$ & VOL $\left(\mathrm{cm}^{3}\right)$ & RT \\
\hline 7 & 3.77 & 3.79 & 3.66 & $4.00^{\star}$ \\
\hline 8 & $4.96^{\star}$ & 3.82 & 2.73 & $4.76^{*}$ \\
\hline 9 & 0.73 & 0.62 & 0.49 & 1.10 \\
\hline 10 & 0.04 & 0.11 & 0.22 & 0.13 \\
\hline 15 & $12.21^{\star}$ & $13.63^{*}$ & $14.29^{\star}$ & $19.39^{*}$ \\
\hline 16 & $5.91^{*}$ & $5.88^{\star}$ & $5.52^{\star}$ & $8.42^{\star}$ \\
\hline 17 & 0.95 & 0.53 & 0.23 & $4.42^{\star}$ \\
\hline 18 & 3.82 & 3.24 & 2.58 & $4.92^{\star}$ \\
\hline 19 & 3.43 & 2.59 & 1.81 & $4.77^{\star}$ \\
\hline 20 & $8.65^{\star}$ & $9.80^{\star}$ & $10.46^{*}$ & $26.93^{*}$ \\
\hline 21 & $5.93^{*}$ & $5.32^{\star}$ & $4.48^{\star}$ & $17.03^{*}$ \\
\hline 22 & $5.90^{\star}$ & $8.11^{\star}$ & $10.28^{*}$ & $9.46^{*}$ \\
\hline 23 & 3.85 & 3.11 & 2.72 & $10.45^{*}$ \\
\hline 24 & 1.23 & 1.11 & 0.97 & $6.41^{\star}$ \\
\hline 25 & 0.67 & 1.03 & 1.39 & $4.54^{*}$ \\
\hline 26 & $5.22^{*}$ & $6.13^{*}$ & $6.69^{*}$ & $3.34^{\star}$ \\
\hline 27 & 0.89 & 1.45 & 2.21 & 0.88 \\
\hline 28 & $4.28^{*}$ & $5.31^{*}$ & $6.11^{*}$ & $5.11^{*}$ \\
\hline
\end{tabular}

*Significant at $5 \%$ probability by the t-test. $\mathrm{H}_{0}: \mathrm{C}_{1}=$ Parents.

For the trait grain yield, promising families for the development of superior lines in relation to the fixed populations (commercial cultivars) have been highlighted. This observation is still valid, even after eight selection cycles, for grain yield as well (Silva et al. 2010; Alves et al. 2015). For traits related to white mold tolerance and resistance, the superiority of progenies of selection cycles over parents was also noticeable (Terán and Singh 2010).

Interestingly, the pedigree of the seven progenies with superior performance for root system-related variables contains combinations of parents of different gene groups (Andean and Middle American). The search for complementary characteristics of the root system morphology among gene groups is an important step in breeding programs (Abenavoli et al. 2015). The recombination of $\mathrm{F}_{2}$ progenies, derived from the combination of Andean and Middle American parents, may increase the possibility of releasing genetic variance and make the "breakup" of possible gene blocks related to root system expression possible. Genotype 16, for example, resulted from the recombination of progenies derived from the genotypes BAF35 $\times$ BRS Embaixador (Middle American $\times$ Andean) and BAF53 $\times$ IPR Uirapuru (Andean $\times$ Middle American).

However, undoubtedly, the best phenotypic performance (as evidenced by the differences between compared means) was observed for genotype 15 (Table 5). This fact is relevant, since this progeny was derived from the recombination of parents BAF35 $\times$ BRS Embaixador (Middle American $\times$ Andean) and IPR Uirapuru $\times$ BRS Embaixador (Middle American $\times$ Andean) This indicates the possible complementary gene action between the parents. In both $\mathrm{C}_{0}$ progenies that constitute genotype 15 , the origin of the maternal parent is Middle American. The paternal parent, on the other hand, is exclusively represented by BRS Embaixador, of Andean origin. The pedigree of genotype BRS Embaixador contains lines of the common bean breeding program of the International Center for Tropical Agriculture (CIAT - Colombia). This center is already developing studies in the search for lines with drought tolerance, for example. Thus, the combination involving these genotypes and in this sequence was possibly responsible for increasing the frequency of favorable alleles for the root system. According to this result, it is extremely relevant to define which parent is most likely to assume the maternal and paternal order in the recombination stages (Singh et al. 2017).

After confirming the effectiveness of a recurrent selection cycle, new plants for the population of the following selection cycle must be selected (Guimarães 1997). The recurrent selection system based on the choice of plants considered superior 
for a given trait, followed by their recombination, is recommendable when the purpose is to combine desirable characteristics to maximize the gain per selection cycle (Ramalli 1996). In this way, by selecting and recombining the best plants for root system variables over several cycles, it is even possible to accumulate a higher number of advantageous alleles in a single plant.

For all traits, phenotypic superiority over the parents and $\mathrm{C}_{0}$ populations was observed for the genotypes $\mathrm{C}_{1}$, which must, therefore, necessarily be included in the next selection cycles. The seven progenies highlighted in Table 5 can be indicated for the next selection cycle. To the end of developing genotype combinations adapted to suboptimal cultivation conditions, the identification and selection of genotypes with a root system with a more efficient uptake of water and mineral elements is a key approach in breeding programs (Beebe et al. 2013; Assefa et al. 2015).

Genotypes possibly more adapted to adverse conditions have a high number of adventitious roots, reduced root diameter, shallow basal roots and a high root hair density (Lynch 2007). In this way, high values for the variables TRL, VOL, PRA and RT considered in this study are directly related to genotypic adaptability.

This study, based on the selection of contrasting lines, hybridizations between these lines and the selection and recombination of better performing progenies, confirmed the relevance of including a range of parents in the crossing stages. Conventional hybridizations resulted in a similar performance of fixed and segregating populations, even when distinct gene groups were included. However, the gains for the root system increase to the extent at which more parents of different gene groups are involved in the establishment of a single progeny. Genetic variation may alter the genotypic population mean for a given variable by raising the frequency of favorable genes and consequently increasing desirable genotype combinations. Thus, the seven progenies of the first selection cycle $\left(\mathrm{C}_{1}\right)$, identified with superior performance in relation to base populations $\left(\mathrm{C}_{0}\right)$ and parents, need to be conducted in the field, self-fertilized and evaluated again for root system traits in future selective cycles.

\section{CONCLUSION}

The first phenotypic recurrent selection cycle for root system was effective. The mean genetic progress per root-related trait was $12.3 \%$. Seven promising new populations were identified to the next recurrent selection cycle. The use of recurrent selection can be an alternative in the identification and development of common bean cultivars with an improved root system.

\section{AUTHORS' CONTRIBUTION}

Conceptualization: Cerutti P. H.; Methodology: Cerutti P. H. and Melo R. C.; Investigation: Cerutti P. H., Melo, R. C. and Silva J. A.; Writing - Original Draft: Cerutti P. H.; Writing - Review and Editing: Cerutti P. H. and Melo R. C.; Funding Acquisition: Coimbra J. L. M.; Resources: Coimbra J. L. M.; Guidolin A. F. and Primieri S.; Supervision: Coimbra J. L. M.; Guidolin A. F.; Fioreze A. C. C. L. and Primieri S.

\section{DATA AVAILABILITY STATEMENT}

All dataset were generated or analyzed in the current study.

\section{FUNDING}

Fundação de Amparo à Pesquisa e Inovação do Estado de Santa Catarina.

[https://doi.org/10.13039/501100005667]

Grant No: 2019TR644 


\section{ACKNOWLEDGMENTS}

We are indebted to Universidade Federal de Santa Catarina (UFSC) and Instituto Federal de Santa Catarina (IFSC) for intellectual support.

\section{REFERENCES}

Abenavoli, M. R., Leone, M., Sunseri, F., Bacchi, M. and Sorgonà, A. (2015). Root phenotyping for drought tolerance in bean landraces from Calabria (Italy). Journal of Agronomy and Crop Science, 202, 1-12. https://doi.org/10.1111/jac.12124

Allard, R. W. (1971). Princípios do melhoramento genético das plantas. São Paulo: Edgard Blucher.

Alves, A. F., Menezes Júnior, J. A. N., Menezes, V. M. P. S., Carneiro, J. E. S., Carneiro, P. C. S and Alves, A. F. (2015). Genetic progress and potential of common bean families obtained by recurrent selection. Crop Breeding and Applied Biotechnology, 15, 218-226. https:// doi.org/10.1590/1984-70332015v15n4a38

Amongi, W., Nkalubo, S. T., Gibson, P., Edema, R. and Ochwo-Ssemakula, M. (2015). Genetics of drought tolerance in common bean genotypes adapted to Ugandan conditions. Journal of Plant Breeding and Crop Science, 7, 18-27. https://doi.org/10.5897/JPBCS2014.0462

Anjos, R. S. R., Poersch, N. L., Batista, L. G., Moura, L. M., Carneiro, J. E. S., Dias, L. A. S. and Carneiro, P. C. S. (2018). Selection for hypocotyl diameter results in genetic gain in common bean plant architecture. Crop Breeding and Applied Biotechnology ,18, 417-425. https:// doi.org/10.1590/1984-70332018v18n4a61

Assefa, T., Wu, J., Beebe, S. E., Rao, I. M., Marcomin, D. and Claude, R. J. (2015) Improving adaptation to drought stress in small red common bean: phenotypic differences and predicted genotypic effects on grain yield, yield components and harvest index. Euphytica, 203, 477- 489. https://doi.org/10.1007/s10681-014-1242-x

Beebe, S E., Rao, I. M., Cajiao, C. and Grajales, M. (2008). Selection for Drought Resistance in Common Bean Also Improves Yield in Phosphorus Limited and Favorable Environments. Crop Science, 48, 582-592. https://doi.org/10.2135/cropsci2007.07.0404

Beebe, S. E., Rao, I. M, Blair, M. W. and Acosta-Gallegos, J. A. (2013). Phenotyping common beans for adaptation to drought. Frontiers in Physiology, 4, 35. https://doi.org/10.3389/fphys.2013.00035

Böhm, W. (1979). Methods of Studying Root Systems. Heidelberg: Springer-Verlag Berlin. https://doi.org/10.1007/978-3-642-67282-8

Fancelli, A. L. and Dourado Neto, D. (2007). Produção de Feijão. Piracicaba: Livroceres.

Fehr, W. R. (1987). Principles of Cultivar Development. New York: Macmillan.

Guimarães, E. P. (1997). Seleccion recurrente en arroz. Cali: CIAT.

Hallauer, A. R. and Darrah, L. L. (1985). Compendium of recurrent selection methods and their application. Critical Reviews in Plant Sciences, 3,1-33. https://doi.org/10.1080/07352688509382202

Henry, A., Rosas. J. C., Beaver, J. S. and Lynch, J. P. (2010). Multiple stress response and belowground competition in multilines of common bean (Phaseolus vulgaris L.). Field Crops Research, 117, 209-218. https://doi.org/10.1016/j.fcr.2010.03.004

Ho, M. D., Rosas, J. C., Brown, K. M, and Lynch, J. P. (2005). Root architectural tradeoffs for water and phosphorus acquisition. Functional plant biology, 32, 737-748. https://doi.org/10.1071/FP05043

Leite, M. E., Dias, J. A., Souza, D. A., Alves, F. C., Pinheiro, L. R. and Santos, J. B. (2016). Increasing the resistance of common bean to white mold though recurrent selection. Scientia Agricola, 73, 71-78 https://doi.org/10.1590/0103-9016-2015-0084 
Lynch, J. P. (2007). Roots of the Second Green Revolution. Australian Journal of Botany, 55, 493-512. https://doi.org/10.1071/BT06118

Melo, R. C., Schmit, R., Cerutti, P. H., Guidolin, A. F. and Coimbra, J. L. M. (2016). Genetic variation in the trait root distribution over segregating generations of common bean. Euphytica, 207, 665-674. https://doi.org/10.1007/s10681-015-1568-z

Miguel, M. A., Widrig, A., Vieira, R. F., Brown, K. M. and Lynch, J. P. (2013). Basal root whorl number: a modulator of phosphorus acquisition in common bean (Phaseolus vulgaris). Annals of Botany, 112, 973-982. https://doi.org/10.1093/aob/mct164

Moura, L. M., Anjos, R. S. R., Batista, R. O., Vale, N. M., Cruz, C. D., Carneiro, J. E. S., Machado, J. C. and Carneiro, P. C. S. (2018). Combining ability of common bean parents in different seasons, locations and generations. Euphytica, 214, 181. https://doi.org/10.1007/ s10681-018-2259-3

Nienhuis, J. and Singh, S. P. (1988). Genetics of Seed Yield and its Components in Common Bean (Phaseolus vulgaris L.) of Middle American Origin: I. General Combining Ability. Plant Breeding, 101, 143-154. https://doi.org/10.1111/j.1439-0523.1988.tb00280.x

Pereira, L. A., Abreu, A. F. B., Vieira Júnior, I. C., Pires, L. P. M. and Ramalho, M. A. P. (2016). Genetic progress estimation strategy for upright common bean plants using recurrent selection. Genetics and Molecular Research, 16, gmr16019494. https://doi.org/10.4238/gmr16019494

Polania, J., Rao, I. M., Cajiao, C., Rivera, M., Raatz, B. and Beebe, S. (2016). Physiological traits associated with drought resistance in Andean and Mesoamerican genotypes of common bean (Phaseolus vulgaris L). Euphytica, 210,17-29. https://doi.org/10.1007/s10681-016-1691-5

Ramalho, M. A. P., Abreu, A. F. B. and Santos, J. B. (2005). Genetic progress after four cycles of recurrent selection for yield and grain traits in common bean. Euphytica, 144, 23-29. https://doi.org/10.1007/s10681-005-5694-x

Ramalli, P. (1996). Phenotypic recurrent selection in common bean (Phaseolus vulgaris L.) based on performance of S2 progenies. Euphytica, 87, 127-132. https://doi.org/10.1007/BF00021885

Román-Avilés, B., Snapp, S. S. and Kelly, J. D. (2003). Assessing root traits associated with root rot resistance in common bean. Field Crops Research, 86, 147-156 https://doi.org/10.1016/j.fcr.2003.08.001

Silva, F. B., Ramalho, M. A. P. and Abreu, A. F. B. (2007). Seleção recorrente fenotípica para florescimento precoce de feijoeiro Carioca. Pesquisa Agropecuária Brasileira, 42,1437-1442. https://doi.org/10.1590/S0100-204X2007001000010

Silva, G. S., Ramalho, M. A. P., Abreu, A. F. B. and Nunes, J. A. R. (2010). Estimation of genetic progress after eight cycles of recurrent selection for common bean grain yield. Crop Breeding and Applied Biotechnology, 10, 351-356. https://doi.org/10.1590/S1984-70332010000400010

Silva, V. M. P., Menezes Júnior, J. A. N., Carneiro, P. C. S., Carneiro, J. E. S. and Cruz, C. D. (2013). Genetic improvement of plant architecture in the common bean. Genetics and Molecular Research, 12, 3093-3102. https://doi.org/10.4238/2013.January.30.8

Silva, D. A., Esteves, J. A. F., Gonçalves, J. G. R., Azevedo, C. V. G., Ribeiro, T., Chiorato, A. F. and Carbonell, S. A. M. (2016). Evaluation of common bean genotypes for phosphorus use efficiency in Eutrophic Oxisol. Bragantia, 75, 152-163. https://doi.org/10.1590/1678-4499.454

Singh, J., Michelangeli, J. A. C., Gezan, S. A., Lee, H. and Vallejos, C. E. (2017). Maternal Effects on Seed and Seedling Phenotypes in Reciprocal F1 Hybrids of the Common Bean (Phaseolus vulgaris L.). Frontiers in Plant Science, 8, 42. https://doi.org/10.3389/fpls.2017.00042

Souza, D. A., Pereira, F. A. C., Dias, J. A., Leite, M. E. and Santos, J. B. (2014). Reaction of common bean progenies to white mold derived from recurrent selection. Ciência Rural, 44, 583 -587. https://doi.org/10.1590/S0103-84782014000400001

Terán, H. and Singh, S. P. (2010). Gamete and recurrent selection for improving physiological resistance to white mold in common bean. Canadian Journal of Plant Science, 90,153-162. https://doi.org/10.4141/CJPS09128

Torres, F. E., Sagrilo, E., Teodoro, P. E., Ribeiro, L. P. and Cargnelutti Filho, A. (2015). Número de repetições para avaliação de caracteres em genótipos de feijão-caupi. Bragantia, 74, 161-168. http://doi.org/10.1590/1678-4499.0393

Vencovsky, R. and Barriga, P. (1992). Genética biométrica no fitomelhoramento. Ribeirão Preto: Sociedade Brasileira de Genética. 